\title{
Working
}

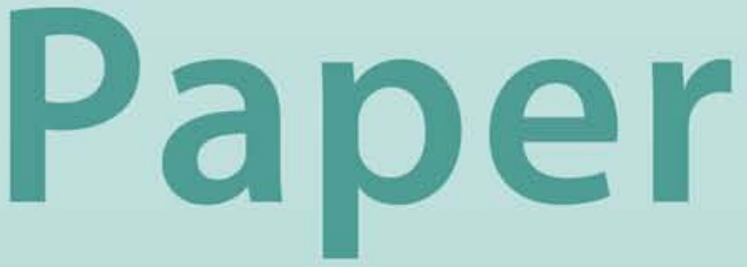


Targets, Interest Rates, and Household Saving in Urban China

Malhar Nabar 


\title{
IMF Working Paper
}

Asia and Pacific Department

\section{Targets, Interest Rates, and Household Saving in Urban China}

Prepared by Malhar Nabar ${ }^{1}$

Authorized for distribution by Nigel Chalk

September 2011

\section{This Working Paper should not be reported as representing the views of the IMF.} The views expressed in this Working Paper are those of the author(s) and do not necessarily represent those of the IMF or IMF policy. Working Papers describe research in progress by the author(s) and are published to elicit comments and to further debate.

\begin{abstract}
This paper studies a panel of China's provinces over the period 1996-2009 during which urban household saving rates increased from 19 percent of disposable income to 30 percent. It finds that the increase in urban saving rates is negatively associated with the decline in real interest rates over this period. This negative association suggests that Chinese households save with a target level of saving in mind. When the return to saving declines (increases), it becomes more difficult (easier) to meet a target and households increase (lower) their saving out of current disposable income to compensate. The results are robust across specifications and to the inclusion of additional variables. A main policy implication is that an increase in real deposit rates may help lower household saving and boost domestic consumption.
\end{abstract}

JEL Classification Numbers: E21, E43, G21, G28

Keywords: China, Household Saving, Target Savings, Financial Liberalization Author’s E-Mail Address:mnabar@imf.org

\footnotetext{
${ }^{1}$ This paper has benefited from detailed comments by Nigel Chalk and Papa N'Diaye, and helpful discussions with Ashvin Ahuja, Steve Barnett, Marcos Chamon, Nan Geng, Kai Guo, Il Houng Lee, Murtaza Syed and seminar participants at the People's Bank of China. Alla Myrvoda provided outstanding research assistance. The author bears all responsibility for errors and omissions.
} 


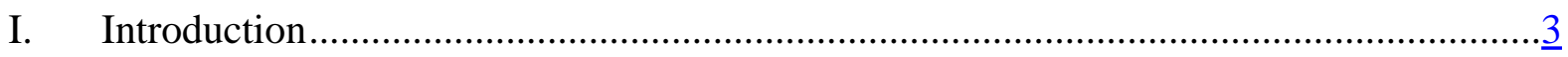

II. Household Saving in China in Recent Years .........................................................

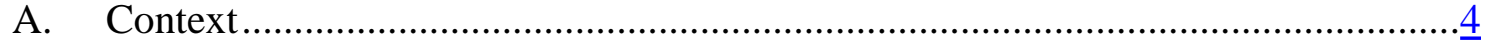

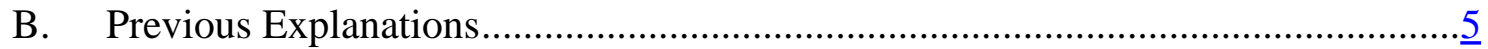

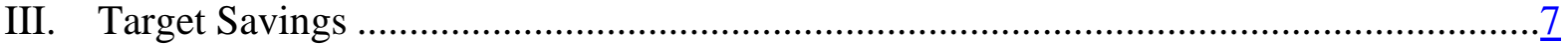

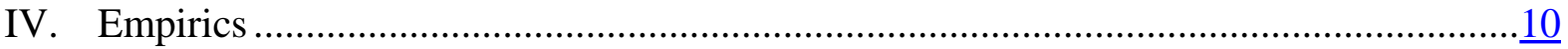

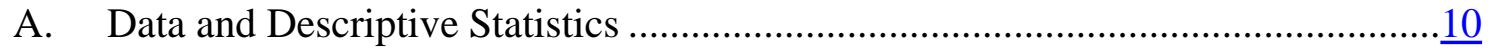

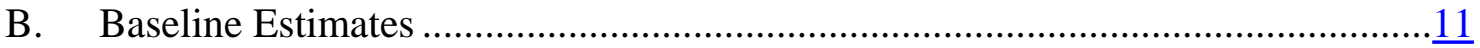

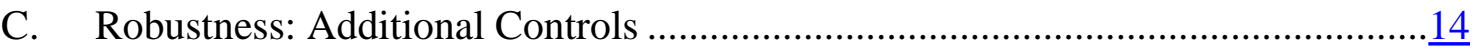

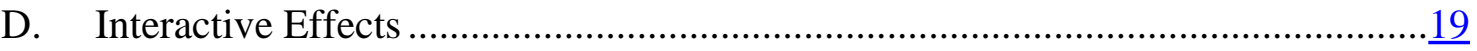

V. Interest Rate Liberalization and Financial Reform ...............................................

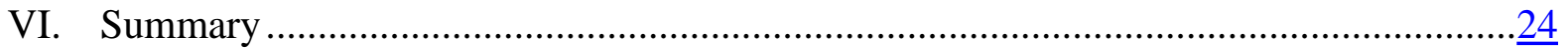

Figures

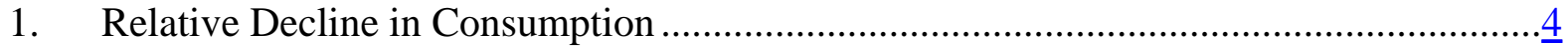

2. Household Saving Rates ....................................................................................... 5

3. Urban Household Saving Rates and Real Interest Rates ............................................

4. Deviation from Provincial Average .....................................................................

Tables

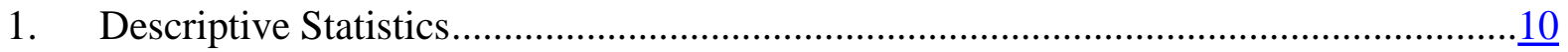

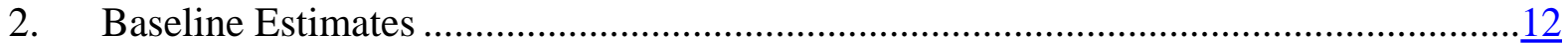

3. Baseline Estimates, Split Samples ........................................................................14

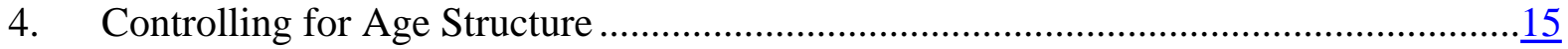

5. Controlling for SOE Share of Employment, Property Income Share ...........................16

6. Controlling for Property Prices..............................................................................

7. Gender Ratios and Household Size......................................................................19

8. Interactive Effects, Interest Rates and Other Saving Motives (All Provinces)...............20

9. Interactive Effects, Interest Rates and Other Saving Motives (Excluding Autonomous

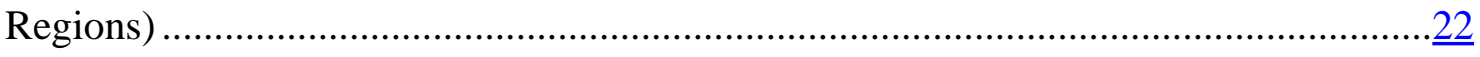

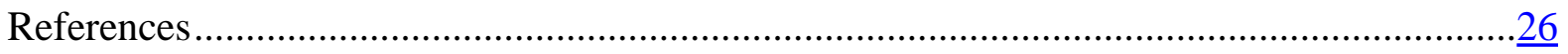




\section{INTRODUCTION}

In the mid-1990s, China's urban household saving rate stood at 19 percent of disposable income. A decade and a half later, the saving rate touched 30 percent. This increase occurred over a period when the economy grew rapidly and expectations of improved livelihoods, higher earnings, and greater prosperity took root. Such influences might have been expected to dampen rather than trigger savings impulses.

At the same time as the household saving rate rose, China's growth model became more reliant on exports and investment. Rebalancing China's economy back toward consumption will require, among other policies, measures that induce households to save less and spend more. This paper examines what role financial reform, in particular interest rate liberalization and an increase in saving deposit rates, can play in influencing household saving rates in China.

Although a large body of research has examined the determinants of household saving in China, little attention has been directed to interest rates and their impact on saving decisions. Bank deposits are currently the primary saving vehicle available to Chinese households. The return households earn on these bank deposits could therefore potentially influence household saving behavior in a tangible way. This research assesses how interest rates affect household saving decisions using a panel dataset that covers China's 31 provincial-level administrative units over the period 1996-2009.

The main findings are as follows.

- $\quad$ Panel estimates suggest that household savings respond strongly to a change in the real interest rate. A one percentage point increase in the real rate of return on bank deposits lowers the urban household saving rate by 0.6 percentage points.

- A comparison of the relationship across sub-periods shows that the association is stronger in the later period, 2003-09, relative to the earlier period, 1996-2002. The relationship is robust to the inclusion of variables that proxy for other influences on saving such as life cycle considerations and self-insurance against income volatility.

- $\quad$ The evidence also indicates that when the return on alternative investment is high (for example when real property price growth is relatively strong), a decline in the real return on bank deposits does not have as negative an impact on household portfolios.

The results suggest that China's households save to meet a multiplicity of needs - retirement consumption, purchase of durables, self-insurance against income volatility and health shocks - and act as though they have a target level of saving in mind. An increase in financial rates of return, which raises the return on saving, makes it easier for them to meet their target saving. Financial reform that boosts interest rates could therefore have a strong effect on current tendencies to save. As financial development proceeds and alternative investment opportunities become more readily available, portfolio diversification may further enable households to meet their target saving more easily. This could potentially contribute to lower rates of saving out of current disposable income. 
The paper is organized as follows. Section II summarizes recent trends in household saving rates in China and provides a brief overview of previous research in this area. Section III outlines the target saving hypothesis, while Section IV presents the empirical analysis. Section $\mathrm{V}$ discusses policy implications and the importance of liberalizing interest rates within the context of an appropriately-sequenced set of financial reforms. Section VI concludes.

\section{HOUSEHOLD SAVING IN CHINA IN RECENT YEARS}

\section{A. Context}

China's economic performance over the past two decades has understandably attracted plenty of attention from policy makers and academic researchers attempting to explain its various dimensions. The transformation of the economy has taken place at an unprecedented pace. By successfully maintaining close to double digit rates of GDP growth for nearly two decades, China has lifted millions out of poverty and the prospects of a middle-class lifestyle are increasingly within the reach of an ever-wider cross section of society. All of this has been accomplished without experiencing any major financial crises or disruptions to growth.

In an economy that has experienced such rapid expansion and accompanying structural transformation in modes of production and distribution, one aspect that has stood out against the backdrop of unprecedented growth is the decline in the household consumption share of GDP and the associated rise in saving rates. Figure 1 (from expenditure-based national accounts data and the flow of funds) shows the relative decline in consumption as a share of GDP over time. As has been previously pointed out, China's consumption share of GDP is

Figure 1. Relative Decline in Consumption (as a share of GDP and disposable income)

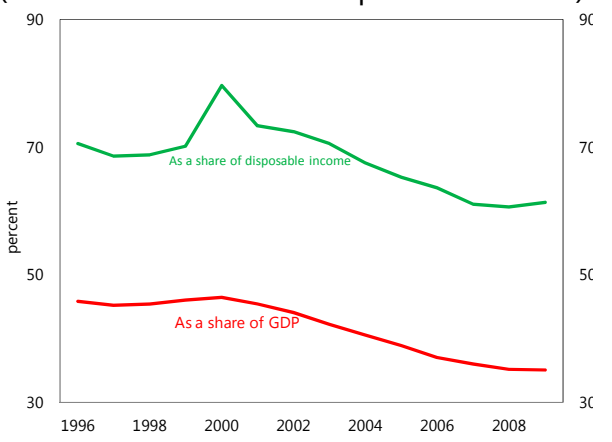
now well below the levels seen in countries with similar levels of per capita income (IMF 2009).

Aziz and Cui (2006) argue that a significant portion of the decline in China's consumption share of GDP can be accounted for by the decline in the share of household disposable income. Furthermore, household interest income as a share of GDP has also fallen in recent years. Lardy (2008) estimates that in the first quarter of 2008, household interest income as a share of GDP was about 4 percentage points lower than would have been the case had households received the same real rates of return on bank deposits as in 2002 (i.e. had nominal rates been adjusted to keep pace with inflation since 2002).

Although shifts in factor income shares might explain some portion of the decline in the consumption share of GDP, as Figure 1 shows consumption has also been falling as a fraction of disposable income. Guo and N'Diaye (2010) argue that China's relatively low private consumption can be accounted for by conditioning factors such as the low level of service sector development, financial development and low real interest rates. Importantly, 
they point out that consumption can be linked to these fundamentals without invoking Chinaspecific cultural attributes as explanatory variables.

The flip-side of a declining consumption share is an increase in the household saving rate. Figure 2 shows the national average urban and rural saving rates computed from household survey data compiled annually by the National Bureau of Statistics. The saving rates are calculated using per capita income and consumption. For the urban series, the measure of income used is disposable income per capita, while for the rural series the measure used is net income per capita. As seen in Figure 2, survey data indicate that urban saving rates have increased over the past decade, with an acceleration in the second half of the time period (i.e. 2003-2009). Rural saving rates have not shown as consistent a pattern: they rose in the late 1990s, before plateauing and then declining slightly. Since 2006, they appear to be on the rise again. This paper focuses on the urban saving rate, leaving the rural saving rate for future analysis.

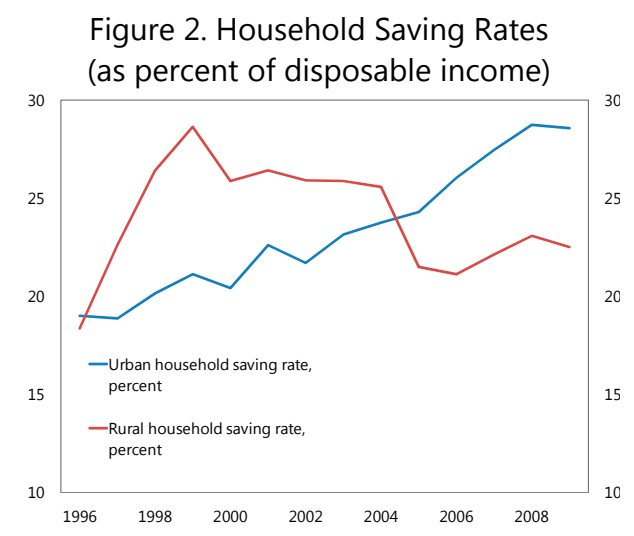

\section{B. Previous Explanations}

Household saving behavior in China has been the focus of considerable empirical research in recent years. Previous work in this area has mainly analyzed survey data drawn from a sample of Chinese cities or specific rural areas (for example, Banerjee et al. 2010; Chamon and Prasad, 2010; Giles and Yoo, 2007). A smaller literature has looked at developments at the national level (Modigliani and Cao, 2004; Kuijs, 2006) or across provinces (Kraay, 2000; Horioka and Wan, 2007; Wei and Zhang, forthcoming). The rise in saving rates has been variously attributed to demographic changes and life cycle considerations, precautionary saving for self-insurance purposes, household formation and spreading homeownership.

Demographic changes and life cycle considerations have been linked to the increase in household saving rates in both macro level analyses (Modigliani and Cao, 2004) and micro level research (Banerjee et al. 2010). Modigliani and Cao (2004) argue that the rise in the saving rate is in line with the predictions of a standard life cycle model where savings follow a hump-shaped profile (negative saving in early years of life give way to positive saving and wealth accumulation in the working years, followed by dissaving during retirement). They point out that China's high growth in recent decades has meant that the saving of the young has more than offset the dissaving of the elderly, leading to a net increase in the saving rate. Banerjee et al. (2010) use a sample of urban households covering nineteen cities across nine provinces and find further evidence in favor of the life cycle model. In the absence of pension systems and developed financial markets, children are in part viewed as a substitute means of old age support. Using the variation in family size induced by the One Child Policy in the 1970s, Banerjee et al. find that family planning policies have contributed to an increase in household saving and wealth accumulation for retirement, with a large portion of the increase coming from households that have a daughter. 
A second category of explanation ties the increase in household saving to a higher private burden of health and education expenditures since the 1990s. This explanation has been advanced for urban households (Chamon and Prasad, 2010) as well as more broadly for the country as a whole (Blanchard and Giavazzi, 2006). Chamon and Prasad (2010) study a sample of urban households drawn from ten provinces / municipalities over 1992-2005, a period in which the iron rice bowl welfare system was dismantled. ${ }^{2}$ They conclude that the decline in public / SOE provision of these important services contributed to an increase in saving across the age distribution of the population. Young households increased their saving to finance education expenditures for their children, while older households saved more to provide a buffer against uncertain health expenditures. Blanchard and Giavazzi (2006) document the rising share of out of pocket expenses in total health spending over the 1990s and the particularly heavy load borne by rural households in this regard. They argue that the self-insurance motive is a key factor behind the rising saving rate over this time period. ${ }^{3}$

A related hypothesis that connects SOE reform, self-insurance and the rising saving rate is put forward by Chamon, Liu and Prasad (2010). The authors use a sample of urban households from nine provinces over the period 1989-2006 to show that higher income uncertainty in the aftermath of SOE reform and restructuring has induced young households to save more over time, while pension reforms and lower retirement benefits has led older households to increase their saving as well. These two developments at opposite ends of the age distribution have contributed to a more pronounced U-shape in the cross-sectional agesaving profile in recent years relative to the 1990s.

Besides SOE reform, another important development in the 1990s was the privatization of the urban housing stock. Chamon and Prasad (2010) find evidence that the increase in saving rates, particularly among young households, is caused in part by homeownership objectives. Homeownership in urban areas has grown rapidly since the initial transfer of the housing stock from SOEs to urban residents often at below-market prices (Naughton, 2007, p.123). However, the spread of mortgage finance has not kept pace and home purchases to a large extent are still almost entirely financed out of saving.

The homeownership and household formation motive also plays a central role in the hypothesis advanced by Wei and Zhang (forthcoming). Their study looks at a province-level panel covering the period 1978-2006 and a sample drawn from the 2002 Chinese Household Income Project. Wei and Zhang's hypothesis is that homeownership is an effective way of

\footnotetext{
${ }^{2}$ See Naughton (2007), Chapters 8 and 13, for an overview of this reform including the restructuring of SOEs. Starting in 1993, more than 30 million SOE workers (around 40 percent of the SOE workforce) were laid off (p.301). The total number of industrial SOEs declined from 120,000 in the mid-1990s to 31,750 in 2004 (p.313).

3 Self-insurance and intra-family in-kind transfers has also had a bearing on other outcomes such as participation in the migrant labor market (Giles and Mu, 2007). In turn, micro level evidence from rural surveys indicates the role of migrant labor networks in determining the strength of the precautionary saving motive: as the size of the migrant labor network expands, both poor and non-poor rural households reduce their precautionary saving when a wider pooling of risks becomes possible (Giles and Yoo, 2007). The importance of intra-family transfers in compensating for the shortfalls of the social safety net has been documented by Cai et al. (2006).
} 
signaling wealth and prosperity in the marriage market, as it raises the probability of securing a good partner in the competitive matching process. The desire to acquire a home as a signaling device induces higher saving prior to the purchase of the home. Wei and Zhang find that households with a son tend to save relatively more in provinces with more skewed sex ratios.

The diverse conclusions from the several studies undertaken pose a challenge for distilling policy implications on what measures might help curb savings and lift consumption growth rates closer to the remarkable rate of GDP growth. Across these studies, the samples differ (urban versus rural, the particular subset of cities studied, and the time periods covered), making it difficult to effectively compare results and draw conclusions on macro developments or policy measures that can be implemented at a national level. Conclusions themselves vary sometimes in diametrically opposite ways: Banerjee et al. (2010) find that households with a daughter increase their saving relatively more and interpret this as a sign that children are substitutes for retirement saving; Wei and Zhang (forthcoming) point out that the households with sons have seen a relatively larger increase in saving and use this to support their argument on homeownership acting as a signal in the competitive marriage market. A further challenge for drawing clear policy messages arises when rising household saving is linked to the growing external imbalance since 2003.

\section{TARGET SAVINGS}

In order to link the increase in saving rates with the widening imbalances and identify possible policy measures that can contribute to the rebalancing effort, we need to find factors that help account for the accelerated increase in saving rates since 2003. One possible factor is the decline in real interest rates that has occurred alongside the rise in saving rates, the shift in the structure of demand, and the increasing reliance on exports and investment over this period (Lardy, 2008). This section provides some motivation and conceptual background for the hypothesis that the decline in real interest rates, particularly in the 20032009 period, has affected urban household saving decisions in a tangible way.

Figure 3 plots the time series for the national average urban saving rate against the real interest rate on bank deposits. Over the period 2003-09, as the real interest rate on bank deposits declined, the urban saving rate

Figure 3. Urban Household Saving Rates and Real Interest Rates (2003-09)

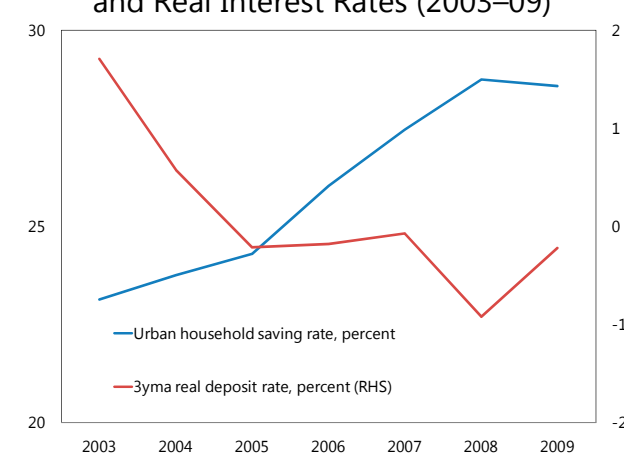
rose steadily. 
Looking more closely at the variation across provinces, a similar negative correlation emerges between province-level urban saving rates and real interest rates on bank deposits. Figure 4 plots the annual province-level deviation from the province average for the post-2003 period of urban saving rates against the similar deviation of real interest rates from their province-specific period average. The scatter plot suggests that across China's provinces, as real interest rates fall relative to their mean, urban saving rates move in the opposite direction and tend to increase relative to average.
Figure 4. Deviation from Provincial Average (post-2003)

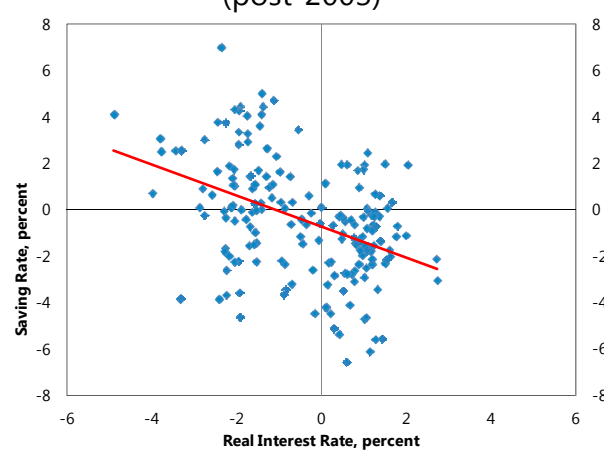

One concern about using the deposit rate as a measure of returns to saving is that it does not take into account the returns on other channels of saving such as wealth management accounts and insurance-linked products. Banerjee et al. (2010) cite estimates from the 2002 China Household Income Project that urban households deposit almost all their saving in banks, with approximately 10 percent held in stocks and bonds. In recent years, as China has been reforming its financial system to allow for non-bank intermediation to emerge, wealth management and insurance-linked products have been growing in importance as alternatives to bank deposits. However, while the heavy reliance on bank deposits may have diminished, they are still the primary channel of household saving (Chamon and Prasad, 2010, p.96). A decline in the return households earn on bank deposits could therefore have a large influence on saving behavior.

An immediate reading of Figures 3 and 4 based on standard intertemporal models of consumption and saving is that the income effect dominates the substitution effect. In other words, as real interest rates fall, the decline in lifetime income is the overriding force that induces households to consume less (and therefore save more) today even though, with lower rates, households have the incentive to do the opposite (i.e. take advantage of the low relative price of current consumption and substitute current consumption for future consumption).

However, a focus on the tension between the income and substitution effects would ignore the rapidly changing context within which Chinese households have been making their spending and saving decisions in recent years. This includes reforms to the social safety net, changes in labor market opportunities and job security, shifting aspirations with regard to the purchase of consumer durables and housing, demographic changes associated with an ageing population and skewed gender ratios, and significant changes in investment returns on household saving portfolios.

In such a rapidly changing environment, with limited use of financial services such as consumer loans, insurance and annuities, households may instead aim to self-insure and build a buffer against income and health shocks, or target a level of wealth accumulation (relative 
to income) to purchase indivisible consumer durables. ${ }^{4}$ In this case, the low returns on saving may cause the actual level of wealth to fall below the targeted level of wealth and induce households to save more in order to make up the shortfall. As described in Carroll (1997, 2001), the "prudence" motive that induces households to save would outweigh the "impatience" motive that prompts consumption. The intuition is seen easily in a simple twoperiod model.

Households earn wages $w_{1}$ and $w_{2}$ respectively in the two periods and earn an interest rate $r$ on first period savings. Suppose they have a desired second period consumption $c_{2}$. Then the utility-maximizing consumption choice in the first period must satisfy the intertemporal budget constraint

$$
c_{2}=\left(w_{1}-c_{1}\right)(1+r)+w_{2}
$$

and the target first period saving $s_{1}\left(=w_{1}-c_{1}\right)$ is given by

$$
s_{1}=\frac{c_{2}-w_{2}}{1+r} \text {. }
$$

For a given desired consumption level $c_{2}$ and second period wage $w_{2}$, the first period saving rate is negatively associated with the real interest rate. In other words,

$$
\frac{\partial s}{\partial r}=\frac{-1}{(1+r)^{2}}<0
$$

The notion that households behave as though they have some target in mind and base their decisions on wanting to achieve their target has been explored in various contexts in recent years. In the macroeconomics literature, Carroll $(1997,2001)$ develops buffer-stock models of saving in which households choose consumption levels at each point in time with the intention of meeting a target wealth-to-income ratio that determines how much of their future consumption will rely on returns from capital relative to labor income. Households adjust their current consumption (and hence their saving) depending on where the actual wealth-toincome ratio is relative to its target level. Batini, N’Diaye, and Rebucci (2005), Laxton, N'Diaye, and Pesenti (2006), and Pesenti (2008) develop open economy DSGE models in which international portfolio diversification is based on a target net foreign asset position, derived from financial intermediaries' assessment of the optimal exposure to the global economy.

Targets have also been studied in the micro literature. Camerer at al. (1997) study the labor supply decisions of New York City cab drivers. Their research concludes that the cab drivers allocate their labor supply with a target income for the day in mind. When the drivers reach their target, the probability of quitting for the day rises sharply. On days when fares are easy

\footnotetext{
${ }^{4}$ This is not to suggest that households target a particular fixed level of wealth or saving. As the scale of the economy grows and income rises, the actual targeted wealth or saving will also evolve in line with other indicators.
} 
to come by, the drivers reach their target relatively quickly and then substitute leisure for labor.

Finally, the empirical literature on household savings in China has already pointed to indirect evidence in support of the target saving hypothesis (Chamon and Prasad, 2010). When real interest rates decline, as they have in recent years, this erodes wealth and leads households to save more to replenish depleted wealth in much the same way as, on slow fare days, NYC cab drivers have to ply more routes for longer hours to meet their income target.

The empirical analysis in the next section studies this hypothesis at more length by looking at developments since 1996 and then by splitting the sample into two sub-periods, 1996-2002 and 2003-2009.

\section{EMPIRICS}

\section{A. Data and Descriptive Statistics}

The data for this study are drawn from annual editions of the China Statistical Yearbook and Urban Household Income and Expenditure Surveys (National Bureau of Statistics). The variables included in the analysis proxy for the main savings motives studied in previous research (summarized in Section II above). The sample covers all 31 provinces, federal municipalities and autonomous regions over the period 1996-2009.

Table 1 reports descriptive statistics for the main variables of interest. The household saving rate is calculated using annual per capita provincial data on urban disposable income and

Table 1. Descriptive Statistics

\begin{tabular}{|c|c|c|c|c|}
\hline Variable & Description & $\begin{array}{l}\text { Full Sample } \\
(1996-2009)\end{array}$ & 1996-2002 & 2003-09 \\
\hline Urban household saving rate & Percent of disposable income & $\begin{array}{l}22.8 \\
(5.2)\end{array}$ & $\begin{array}{l}20.0 \\
(3.9)\end{array}$ & $\begin{array}{l}25.5 \\
(5.0)\end{array}$ \\
\hline Real interest rate & Percent, pa & $\begin{array}{r}1.4 \\
(2.5)\end{array}$ & $\begin{array}{r}2.9 \\
(2.1)\end{array}$ & $\begin{array}{l}-0.1 \\
(1.8)\end{array}$ \\
\hline Growth rate of disposable income & Percent & $\begin{array}{l}10.6 \\
(4.0)\end{array}$ & $\begin{array}{l}10.6 \\
(5.2)\end{array}$ & $\begin{array}{l}10.6 \\
(2.1)\end{array}$ \\
\hline Income volatility & Percent (coefficient of variation, disposable income growth) & $\begin{array}{l}13.4 \\
(5.0)\end{array}$ & $\begin{array}{l}12.7 \\
(6.4)\end{array}$ & $\begin{array}{l}14.1 \\
(2.9)\end{array}$ \\
\hline Elderly dependency ratio & Population $65+$ / working age population, percent & $\begin{array}{l}11.2 \\
(2.5)\end{array}$ & $\begin{array}{l}10.3 \\
(2.3)\end{array}$ & $\begin{array}{l}12.2 \\
(2.4)\end{array}$ \\
\hline Child dependency ratio & Population below 15 / working age population, percent & $\begin{array}{l}30.9 \\
(9.0)\end{array}$ & $\begin{array}{l}34.8 \\
(8.3)\end{array}$ & $\begin{array}{l}26.5 \\
(7.6)\end{array}$ \\
\hline SOE share & Fraction of workers employed by SOEs & $\begin{array}{r}68.2 \\
(13.5)\end{array}$ & $\begin{array}{r}73.4 \\
(10.2)\end{array}$ & $\begin{array}{r}62.2 \\
(14.4)\end{array}$ \\
\hline Urban property income & Property income share of total disposable income & $\begin{array}{r}1.8 \\
(1.2)\end{array}$ & $\begin{array}{r}1.9 \\
(1.3)\end{array}$ & $\begin{array}{r}1.7 \\
(1.0)\end{array}$ \\
\hline Residential property prices & $\mathrm{RMB} / \mathrm{sq} \mathrm{m}$ & $\begin{array}{r}2407 \\
(1706)\end{array}$ & $\begin{array}{l}1666.4 \\
(892.6)\end{array}$ & $\begin{array}{l}2860.9 \\
(1916)\end{array}$ \\
\hline Real property price growth (residential) & y/y percent change & $\begin{array}{r}7.9 \\
(10.9)\end{array}$ & $\begin{array}{r}4.8 \\
(9.7)\end{array}$ & $\begin{array}{r}9.4 \\
(11.2)\end{array}$ \\
\hline Sex ratio & Number of males per 100 females & $\begin{array}{r}103.8 \\
(3.5)\end{array}$ & $\begin{array}{r}104.7 \\
(3.3)\end{array}$ & $\begin{array}{l}103.1 \\
(3.39)\end{array}$ \\
\hline Household size & Average number of residents in a household & $\begin{array}{r}3.5 \\
(0.5)\end{array}$ & $\begin{array}{r}3.7 \\
(0.5)\end{array}$ & $\begin{array}{r}3.3 \\
(0.43)\end{array}$ \\
\hline Adminstrative units & Provinces, federal municipalities, autonomous regions & 31 & 31 & 31 \\
\hline Observations & Province-year units & 429 & 212 & 217 \\
\hline
\end{tabular}

Notes: Standard deviation in parentheses.

Data sources: China Statistical Yearbook, Urban Household Income and Expenditure Survey (National Bureau of Statistics). Number of observations reported in each sample is for urban household saving rates; number of observations for other variables vary depending on data availability. 
urban consumption expenditure. The real interest rate is calculated using the one-year nominal interest rate on bank deposits deflated by province-level annual inflation. As seen from the table, the averages for the two series move in opposite directions across the two sub-intervals.

At the same time, there have been several notable changes during this period which are likely to have had some bearing on saving decisions. Income volatility has increased, leaving workers exposed to more variable earnings. The age distribution of the population has shifted to the right, with a slight increase in the elderly dependency ratio and an appreciable decline in the child dependency ratio - both demographic shifts suggest that life cycle saving influences could also have had an impact on household saving rates during this time. Signs of SOE reform and restructuring are evident in the sharp decline in the fraction of workers employed by SOEs, a change that has left workers with a less comprehensive safety net than they had been accustomed to previously. Finally, real property price growth accelerated over the second half of the sample and average household size declined. Both developments point to rising demand for residential property and increases in homeownership, changes that could have accelerated the rise in saving rates to finance purchases of housing and other durable assets. As discussed in more detail below, these changes could have also simultaneously affected the real interest rate even as they had an impact on saving decisions, which would argue for their inclusion in the empirical analysis to avoid problems of omitted variable bias.

The remainder of this section provides estimates of the influence of these various determinants and assesses what impact the decline in real interest rates has had on urban household saving rates. Baseline estimates from three different specifications are presented first, before robustness tests are conducted using the variables listed in Table 1.

\section{B. Baseline Estimates}

The main specification is

$$
s_{j, t}=\mu_{j}+\beta_{1} X_{j, t}+\beta_{2} r_{j, t}+\varepsilon_{j, t}
$$

where the saving rate is regressed on a vector of covariates $X$ and the real interest rate. In the baseline version, the covariates include the growth rate of income and volatility. Additional controls are introduced in the robustness tests.

The main coefficient of interest is $\beta_{2}$. A statistically significant finding of $\beta_{2}<0$ would indicate that the decline in real interest rates since the 1990s could have potentially contributed to the increase in the saving rate.

\section{OLS and Fixed Effects.}

Table 2 reports results from the OLS and Fixed Effects regressions. The first column confirms a statistically significant negative correlation between real interest rates and urban saving rates across the sample. The magnitude is economically significant as well. A decline in real interest rates from the average for the first half of the sample (2.9 percent) to the average for the second half of the sample (-0.1 percent) is associated with an approximately $1 \frac{1}{2}$ percentage point increase in the saving rate. 
Table 2. Baseline Estimates

\begin{tabular}{|c|c|c|c|c|}
\hline & OLS & \multicolumn{3}{|c|}{ Fixed Effects } \\
\hline Real interest rate & $\begin{array}{c}-0.483^{\star \star \star} \\
(0.104)\end{array}$ & $\begin{array}{c}-0.550^{\star \star *} \\
(0.0826)\end{array}$ & & \\
\hline Nominal interest rate & & & $\begin{array}{c}-1.775^{* * *} \\
(0.235)\end{array}$ & \\
\hline CPI inflation & & & & $\begin{array}{c}0.0388 \\
(0.0701)\end{array}$ \\
\hline Growth rate of income & $\begin{array}{c}-0.597^{\star *} \\
(0.244)\end{array}$ & $\begin{array}{c}-0.779^{\star \star \star} \\
(0.196)\end{array}$ & $\begin{array}{c}0.327 \\
(0.236)\end{array}$ & $\begin{array}{c}-1.250^{\star \star *} \\
(0.180)\end{array}$ \\
\hline Volatility of income & $\begin{array}{c}0.547^{\star \star *} \\
(0.184)\end{array}$ & $\begin{array}{c}0.583^{\star * *} \\
(0.160)\end{array}$ & $\begin{array}{l}0.382^{\star \star} \\
(0.141)\end{array}$ & $\begin{array}{c}1.011^{\star \star *} \\
(0.145)\end{array}$ \\
\hline SAMPLE YEARS & 1996-2009 & $1996-2009$ & 1996-2009 & 1996-2009 \\
\hline Number of provinces / regions / municipalities & 31 & 31 & 31 & 31 \\
\hline Observations & 428 & 428 & 428 & 428 \\
\hline R-squared & 0.14 & 0.24 & 0.37 & 0.17 \\
\hline
\end{tabular}

Notes: Dependent variable: Urban saving rate.

Robust standard errors in parentheses. ${ }^{* \star *} p<0.01,{ }^{* *} p<0.05,{ }^{*} p<0.1$

The two other covariates included in the regression are standard proxies for life cycle saving influences and precautionary saving motives (Kraay 2000, Horioka and Wan, 2007). ${ }^{5}$ If the realized growth rate of income is regarded as a predictor of future income growth, an increase in the growth rate of income should be associated with a decrease in current saving rates since households will defer retirement saving to a future stage in the life cycle (Chamon, Liu, and Prasad, 2010). This prediction is borne out by the negative coefficient on the growth rate of mean disposable income in Column 1. The OLS regression also indicates that higher income volatility is associated with an increase in the saving rate, suggesting that households hold back on consumption and prefer to build up their buffer against future shocks when income uncertainty increases.

The regression in Column 2 controls for time-invariant province-level fixed effects. The fixed effects primarily capture locational differences (coastal versus interior provinces) that affect the economic environment in which the saving decisions are made and real interest rates are determined. The statistical significance and signs of all three coefficients are robust to this change in specification. In particular, the real interest rate continues to be negatively associated with the urban saving rate, suggesting that a decline in the rate of return on household saving leads to a compensating increase in the saving rate.

\footnotetext{
5 The growth rate of mean disposable income is calculated as annual percent change of 4 year moving averages and the volatility of disposable income is calculated as the coefficient of variation over 4 year windows.
} 
An immediate concern is that the real interest rate is simply reflecting variations in the inflation rate rather than the financial (nominal) rate of return on bank deposits. Columns 3 and 4 report results from fixed effects regressions that separately introduce the nominal rate of return and the inflation rate. Although the nominal interest rate is administered centrally and is identical across provinces, there is variation over time in its level. The effects can be distinguished from general year effects because there are multiple instances of the nominal interest rate remaining unchanged across years. In other words, the number of distinct observations for the nominal interest rate is fewer than the number of years in the sample. Of course, if there is an omitted variable that changes at exactly the same time as the nominal interest rate does, this will prevent inference on the effects of the nominal interest rate, but this seems unlikely. The results in Columns 3 and 4 indicate that the coefficient on the nominal interest rate is negative and significant, but that there is an absence of a statistically significant relationship between inflation and the saving rate. This suggests that it is indeed the financial rate of return that seems to matter for the effect of the real interest rate reported in Columns 1 and 2.

\section{Panel GMM Estimation}

To allow for the possibility that saving behavior is persistent, the regressions in Table 3 introduce lagged saving rates to the set of regressors. Since the introduction of the lagged dependent variable biases fixed effects estimates, the specification used is Arellano-Bond panel GMM estimation which allows for the inclusion of the lagged saving rate along with other explanatory variables.

The first column shows that the relationship is robust to this change in specification. However, when the sample period is split into the two sub-intervals (1996-2002 and 20032009), as seen from Columns 2 and 3, the effect is significant only in the second sub-period. This suggests that the association has emerged in recent years, as the decline in real interest rates have become more entrenched over time.

Columns 4-6 repeat the specifications but for a smaller sample that excludes the five autonomous regions (Guangxi, Inner Mongolia, Ningxia, Xinjiang, Xizang/ Tibet). ${ }^{6}$ The pattern is robust to focusing only on the smaller subset of provinces: even after the autonomous regions are excluded, the association between real interest rates and urban saving rates is negative and significant in the second half of the sample period. The absolute value of the coefficient on the real interest rate in Column 6 is slightly smaller than the corresponding coefficient in Column 3, suggesting that saving rates are slightly less responsive to changes in the interest rate in the group of 26 provinces and federal municipalities than they are for the larger sample covering all 31 province-level administrative units.

\footnotetext{
${ }^{6}$ Variations in population policy, which affect the ethnic populations in the autonomous regions differently from the rest of the country, may introduce differences in saving behavior between the autonomous regions as a group and the rest of the country. See Gu et al. (2007) on the exemptions to the One Child Policy and details of variations in implementation across the provinces.
} 
Table 3. Baseline Estimates, Split Samples

\begin{tabular}{|c|c|c|c|c|c|c|}
\hline & (1) & (2) & (3) & (4) & (5) & (6) \\
\hline Lagged saving rate & $\begin{array}{l}0.736^{\star \star \star} \\
(0.0740)\end{array}$ & $\begin{array}{c}0.192 \\
(0.128)\end{array}$ & $\begin{array}{c}0.720^{\star \star \star} \\
(0.108)\end{array}$ & $\begin{array}{l}0.638^{\star \star \star} \\
(0.0364)\end{array}$ & $\begin{array}{c}0.161 \\
(0.115)\end{array}$ & $\begin{array}{l}0.593^{\star \star \star} \\
(0.0778)\end{array}$ \\
\hline Real interest rate & $\begin{array}{l}-0.167^{*} \\
(0.0860)\end{array}$ & $\begin{array}{c}0.148 \\
(0.144)\end{array}$ & $\begin{array}{c}-0.177^{\star * *} \\
(0.0680)\end{array}$ & $\begin{array}{c}-0.110 \\
(0.0747)\end{array}$ & $\begin{array}{c}0.114 \\
(0.137)\end{array}$ & $\begin{array}{c}-0.155^{\star *} \\
(0.0702)\end{array}$ \\
\hline Growth rate of income & $\begin{array}{l}-0.0549 \\
(0.110)\end{array}$ & $\begin{array}{c}-0.487^{\star *} \\
(0.201)\end{array}$ & $\begin{array}{c}0.303 \\
(0.191)\end{array}$ & $\begin{array}{l}-0.120 \\
(0.124)\end{array}$ & $\begin{array}{c}-0.536^{\star \star \star} \\
(0.205)\end{array}$ & $\begin{array}{l}0.0227 \\
(0.271)\end{array}$ \\
\hline Volatility of income & $\begin{array}{c}0.0340 \\
(0.0945)\end{array}$ & $\begin{array}{l}0.317^{\star *} \\
(0.160)\end{array}$ & $\begin{array}{c}-0.00429 \\
(0.128)\end{array}$ & $\begin{array}{l}0.0864 \\
(0.104)\end{array}$ & $\begin{array}{l}0.337^{\star *} \\
(0.162)\end{array}$ & $\begin{array}{c}0.172 \\
(0.156)\end{array}$ \\
\hline SAMPLE YEARS & $1996-2009$ & $1996-2002$ & $2003-09$ & 1996-2009 & $1996-2002$ & $2003-09$ \\
\hline Autonomous regions included & YES & YES & YES & NO & NO & NO \\
\hline Number of provinces / regions / municipalities & 31 & 31 & 31 & 26 & 26 & 26 \\
\hline Observations & 394 & 177 & 217 & 335 & 153 & 182 \\
\hline $\begin{array}{l}\text { Arellano Bond test of no second order } \\
\text { autocorrelation in first-differenced } \\
\text { errors ( } p \text {-value) }\end{array}$ & 0.57 & 0.88 & 0.51 & 0.51 & 0.70 & 0.80 \\
\hline
\end{tabular}

\section{Robustness: Additional Controls}

Although the panel GMM estimation controls for the two main variables used in provincelevel macro analyses of the determinants of saving rates in China (growth rate of disposable income and volatility), concerns remain that the coefficient on the real interest rate may be soaking up the influence of other omitted variables that affect the saving rate. This subsection considers the main hypothesis put forward from the survey-based micro literature. All regressions are estimated over the period 2003-2009, during which the negative association between real interest rates and urban saving rates appears to have emerged.

\section{Age distribution}

As noted above, the age structure of the population has been changing rapidly in China, in part due to the One Child Policy instituted in the 1970s, in part due to improvements in health care, and also because of changes in desired fertility. Changes in the age structure could potentially trigger changes in spending patterns that influence consumer prices and thus the real interest rate, even as they directly influence the saving rate. This would point to potential omitted variables bias in the baseline regressions reported in Tables 2 and 3 above.

Table 4 reports results from regressions that include the elderly dependency ratio and the child dependency ratio measured by province. Columns 1 and 2 study the effects of the elderly dependency ratio for the full set of provinces and for the subset excluding the autonomous regions respectively. The relationship between the real interest rate and the saving rate is robust to the inclusion of the elderly dependency ratio and the magnitude itself 
is larger than in the baseline (Table 3, Columns 3 and 6). The coefficient on the elderly dependency ratio itself is robust and suggests that as the population ages, saving rates increase possibly to finance larger health expenditures.

The final two columns report estimates from regressions that include the child dependency ratio. Here, the coefficient on the real interest rate is no longer statistically significant. Although the coefficient is not statistically significant, the negative relationship between the real interest rate and the urban saving rate emerges in the sample that excludes autonomous regions. The child dependency ratio itself is associated negatively with the saving rate, suggesting that children and financial saving are possible substitutes in the sense that as the number of children declines, the potential for intergenerational transfers later in life diminishes, leading parents to save more today. The effect is robust to changing the sample. As Column 3 and 4 demonstrate, the effect is present regardless of whether the entire set of provinces is included or only the subset excluding the autonomous regions is studied. Thus, variations in the implementation of the One Child Policy across the autonomous regions compared with the remaining provinces do not seem to affect the relationship between the child dependency ratio and the urban saving rate. It is therefore difficult to establish whether changes in desired fertility or the effects of the policy lie behind the negative relationship between the child dependency ratio and the urban saving rate.

Table 4. Controlling for Age Structure

\begin{tabular}{|c|c|c|c|c|}
\hline & (1) & (2) & (3) & (4) \\
\hline Lagged saving rate & $\begin{array}{c}0.653^{* * *} \\
(0.123)\end{array}$ & $\begin{array}{c}0.446^{* * *} \\
(0.101)\end{array}$ & $\begin{array}{l}0.485^{* * *} \\
(0.0732)\end{array}$ & $\begin{array}{c}0.326^{* * *} \\
(0.110)\end{array}$ \\
\hline Real interest rate & $\begin{array}{c}-0.315^{\star *} \\
(0.153)\end{array}$ & $\begin{array}{c}-0.204^{\star * *} \\
(0.0733)\end{array}$ & $\begin{array}{c}0.00871 \\
(0.115)\end{array}$ & $\begin{array}{r}-0.0459 \\
(0.104)\end{array}$ \\
\hline Growth rate of income & $\begin{array}{c}0.199 \\
(0.255)\end{array}$ & $\begin{array}{l}0.0782 \\
(0.299)\end{array}$ & $\begin{array}{c}0.129 \\
(0.239)\end{array}$ & $\begin{array}{c}0.169 \\
(0.255)\end{array}$ \\
\hline Volatility of income & $\begin{array}{l}0.0257 \\
(0.138)\end{array}$ & $\begin{array}{c}0.178 \\
(0.149)\end{array}$ & $\begin{array}{c}-0.0196 \\
(0.131)\end{array}$ & $\begin{array}{c}0.112 \\
(0.147)\end{array}$ \\
\hline Elderly dependency ratio & $\begin{array}{l}0.351^{*} \\
(0.182)\end{array}$ & $\begin{array}{c}0.190 \\
(0.181)\end{array}$ & & \\
\hline Child dependency ratio & & & $\begin{array}{c}-0.597^{* *} \\
(0.262)\end{array}$ & $\begin{array}{c}-0.306^{\star \star} \\
(0.148)\end{array}$ \\
\hline SAMPLE YEARS & 2003-09 & $2003-09$ & 2003-09 & $2003-09$ \\
\hline Autonomous regions included & YES & NO & YES & NO \\
\hline Number of provinces / regions / municipalities & 31 & 26 & 31 & 26 \\
\hline Observations & 186 & 156 & 186 & 156 \\
\hline $\begin{array}{l}\text { Arellano Bond test of no second order } \\
\text { autocorrelation in first-differenced } \\
\text { errors ( } p \text {-value) }\end{array}$ & 0.49 & 0.99 & 0.58 & 0.96 \\
\hline
\end{tabular}




\section{Employment structure and sources of household income.}

The SOE reform and restructuring of the 1990s, involving mass layoffs and downsizing (the number of SOEs went from 120,000 in the mid-1990s to 31,750 in 2004 and nearly 40 percent of the SOE workforce was laid off during this time - see Naughton, 2007, for details) introduced significant and far-reaching changes in labor market prospects, retirement income security, health insurance, and ownership of the urban housing stock. Such a shift in the implicit social safety net would be expected to trigger large changes in household spending and saving decisions. Comparing across provinces and over time, as SOE influence declines (captured by SOE share of employees), we should see a rise in saving rates to protect against the higher uncertainty that the workers formerly employed by SOEs are now exposed to.

Table 5. Controlling for SOE Share of Employment, Property Income Share

\begin{tabular}{|c|c|c|c|c|}
\hline & (1) & (2) & (3) & (4) \\
\hline Lagged saving rate & $\begin{array}{c}0.630^{\star * *} \\
(0.143)\end{array}$ & $\begin{array}{c}0.307^{\star \star *} \\
(0.113)\end{array}$ & $\begin{array}{l}0.579 * * * \\
(0.0751)\end{array}$ & $\begin{array}{l}0.432^{* * *} \\
(0.0982)\end{array}$ \\
\hline Real interest rate & $\begin{array}{c}-0.259^{\star *} \\
(0.128)\end{array}$ & $\begin{array}{c}-0.177^{\star *} \\
(0.0722)\end{array}$ & $\begin{array}{c}-0.286^{\star \star} \\
(0.127)\end{array}$ & $\begin{array}{c}-0.192^{\star * *} \\
(0.0731)\end{array}$ \\
\hline Growth rate of income & $\begin{array}{c}-0.0758 \\
(0.264)\end{array}$ & $\begin{array}{l}0.0321 \\
(0.250)\end{array}$ & $\begin{array}{c}-0.0168 \\
(0.294)\end{array}$ & $\begin{array}{l}0.0549 \\
(0.271)\end{array}$ \\
\hline Volatility of income & $\begin{array}{l}0.0699 \\
(0.113)\end{array}$ & $\begin{array}{l}0.0966 \\
(0.130)\end{array}$ & $\begin{array}{l}0.0402 \\
(0.137)\end{array}$ & $\begin{array}{c}0.160 \\
(0.147)\end{array}$ \\
\hline SOE share of employment & $\begin{array}{c}-0.231^{\star * *} \\
(0.0668)\end{array}$ & $\begin{array}{c}-0.208^{\star * *} \\
(0.0589)\end{array}$ & & \\
\hline Property income share & & & $\begin{array}{l}1.939^{\star} \\
(1.054)\end{array}$ & $\begin{array}{l}0.669^{* *} \\
(0.314)\end{array}$ \\
\hline SAMPLE YEARS & 2003-09 & 2003-09 & $2003-09$ & 2003-09 \\
\hline Autonomous regions included & YES & NO & YES & NO \\
\hline Number of provinces / regions / municipalities & 31 & 26 & 31 & 26 \\
\hline Observations & 186 & 156 & 186 & 156 \\
\hline $\begin{array}{l}\text { Arellano Bond test of no second order } \\
\text { autocorrelation in first-differenced } \\
\text { errors ( } p \text {-value) }\end{array}$ & 0.45 & 0.94 & 0.48 & 0.90 \\
\hline
\end{tabular}

If SOE reforms and restructuring also affected production and distribution networks and introduced significant provincial level variation in pricing of consumer products, the reforms would have been associated with fluctuations in the underlying structural inflation rate across provinces, and thus the real interest rate. Columns 1 and 2 of Table 5 include the SOE share of employment as an additional robustness check. The relationship between the real interest rate and the household saving rate is robust to including this proxy for the erosion of the 
implicit social safety net previously provided by SOEs. Further, the coefficient on the SOE share goes in the direction predicted by theory. As the SOE share declines, household saving rates rise to strengthen household defenses against higher income volatility and a less comprehensive social insurance mechanism.

Along with SOE reform, in the 1990s households also received a large transfer from the state in the form of residential property stock and the potential for another form of income through rents. To the extent that provinces where households come to rely on property income as a more important source of disposable income also experienced more rapid increases in inflation (which triggered larger declines in the real interest rate), a regression that fails to include property income share as an additional control will be subject to omitted variable bias. To address this concern, Columns 3 and 4 report results from regressions where the property income share of household disposable income is included as an additional control. The relationship between the real interest rate and the urban household saving rate is robust to including this additional control. The sign on the coefficient itself suggests that in provinces where households depend more on property income, households tend to have higher saving rates out of disposable income possibly since there are more productive saving opportunities available (such as through the purchase of residential property that can then be rented out).

\section{Saving to buy property}

The privatization of urban housing stock starting in the late 1990s introduced a noticeable change in household tenure choice decisions with an increasing fraction of urban households choosing to buy homes over time (by 2005, the proportion of owner-occupied urban housing units has exceeded 80 percent, up from 48 percent in 1999 - Naughton, 2007, p.123). Housing finance options have remained limited, however, as bank lending continues to be primarily focused on enterprises (only 13 percent of the outstanding loan portfolio as of end2010 was allocated to residential mortgages). As a result, one possible explanation for the rapid increase in household saving is that it is intended for housing purchase. In an environment where homeownership is increasingly widespread, we would expect that saving decisions conform over time as households plan for an eventual home purchase.

To the extent that rapid house price increases are associated with other relatively more rapid general consumer price growth, residential property prices could have a negative association with real interest rates even as they are positively associated with the urban saving rate. This raises yet another concern of omitted variable bias in the regressions reported in Table 3 .

The regressions reported in Table 6 use two proxies to control for the influence of the property motive: the level of the residential property price and the growth rate of real property prices. Columns 1 and 2 indicate that the association between the real interest rate and urban saving rates is robust to including the level of the residential property price. The pattern is repeated in Columns 3 and 4 when the growth rate of real property prices is introduced. The property motive itself is significant in the first two columns, indicating that urban saving rates tend to be higher in provinces with high levels of property prices. 
Table 6. Controlling for Property Prices

\begin{tabular}{|c|c|c|c|c|}
\hline & (1) & (2) & (3) & (4) \\
\hline Lagged saving rate & $\begin{array}{l}0.617^{\star * *} \\
(0.0598)\end{array}$ & $\begin{array}{l}0.385^{\star * *} \\
(0.0789)\end{array}$ & $\begin{array}{l}0.712^{* * *} \\
(0.0400)\end{array}$ & $\begin{array}{l}0.733^{* * *} \\
(0.0789)\end{array}$ \\
\hline Real interest rate & $\begin{array}{c}-0.254^{* * *} \\
(0.0788)\end{array}$ & $\begin{array}{c}-0.191^{\star * *} \\
(0.0628)\end{array}$ & $\begin{array}{l}-0.177^{* *} \\
(0.0799)\end{array}$ & $\begin{array}{c}-0.144^{*} \\
(0.0733)\end{array}$ \\
\hline Growth rate of income & $\begin{array}{l}-0.233 \\
(0.301)\end{array}$ & $\begin{array}{l}-0.135 \\
(0.252)\end{array}$ & $\begin{array}{c}0.294 \\
(0.201)\end{array}$ & $\begin{array}{c}0.154 \\
(0.278)\end{array}$ \\
\hline Volatility of income & $\begin{array}{l}0.0952 \\
(0.125)\end{array}$ & $\begin{array}{c}0.111 \\
(0.136)\end{array}$ & $\begin{array}{c}0.000660 \\
(0.129)\end{array}$ & $\begin{array}{c}0.147 \\
(0.168)\end{array}$ \\
\hline Property prices & $\begin{array}{c}3.283^{* * *} \\
(0.807)\end{array}$ & $\begin{array}{c}3.335^{\star * *} \\
(0.669)\end{array}$ & & \\
\hline Real property price growth & & & $\begin{array}{c}0.000693 \\
(0.0113)\end{array}$ & $\begin{array}{r}-0.00841 \\
(0.0127)\end{array}$ \\
\hline SAMPLE YEARS & 2003-09 & 2003-09 & $2003-09$ & $2003-09$ \\
\hline Autonomous regions included & YES & NO & YES & NO \\
\hline Number of provinces / regions / municipalities & 31 & 26 & 31 & 26 \\
\hline Observations & 217 & 182 & 217 & 182 \\
\hline $\begin{array}{l}\text { Arellano Bond test of no second order } \\
\text { autocorrelation in first-differenced } \\
\text { errors ( } p \text {-value) }\end{array}$ & 0.50 & 0.89 & 0.14 & 0.11 \\
\hline
\end{tabular}

Notes: Dependent variable: Urban saving rate. Panel GMM estimation.

Robust standard errors in parentheses. ${ }^{* *} p<0.01,{ }^{* *} p<0.05,{ }^{*} p<0.1$

\section{Additional household attributes}

A final set of robustness checks introduces the gender ratio and average household size as additional controls. The gender composition of the population may influence marriage prospects, household formation, and the impulse to save in order to purchase a home (Wei and Zhang, forthcoming). To the extent that marriages are largely formed within the province (i.e. few matches take place across provinces), provincial variation in the gender composition (number of males per 100 females) can be used as a proxy for the household formation motive for saving.

Average household size reflects the influence that the number of co-residents may have on the saving rate of the average household. As household size increases, there are at least two possible effects on saving. First, a larger household could imply more co-resident adults (elderly, for example) and so greater possibilities to tap into resources accumulated through their past saving. Second, variation in household size could arise also due to the number of children in the home. Those households with a child may be relatively less concerned about saving for retirement purposes than those households without a child since the possibilities for intergenerational transfers are greater in the first set. 
As the first two columns in Table 7 indicate, introducing the variation of gender composition as an additional control does not affect the significance or the sign of the coefficient on the real interest rate. The gender composition itself does not have a significant effect on the urban saving rate. This may in part reflect two competing effects that cancel each other. A larger number of males relative to females may lead to lower saving for retirement since there may be an expectation of a greater degree of intergenerational transfer from the male child to the elderly parents relative to the transfers that potentially take place from a female child. But an increase in the sex ratio may increase the competition for marriage matches and therefore strengthen motives to save in order to purchase a home.

Table 7. Gender Ratios and Household Size

\begin{tabular}{|c|c|c|c|c|}
\hline & (1) & (2) & (3) & (4) \\
\hline Lagged saving rate & $\begin{array}{l}0.718^{\star * *} \\
(0.0445)\end{array}$ & $\begin{array}{l}0.593^{\star \star *} \\
(0.0774)\end{array}$ & $\begin{array}{l}0.752^{* * \star} \\
(0.0453)\end{array}$ & $\begin{array}{l}0.743^{\star * *} \\
(0.0651)\end{array}$ \\
\hline Real interest rate & $\begin{array}{c}-0.191^{\star \star} \\
(0.0836)\end{array}$ & $\begin{array}{l}-0.159^{* *} \\
(0.0704)\end{array}$ & $\begin{array}{l}-0.178^{\star \star} \\
(0.0870)\end{array}$ & $\begin{array}{c}-0.193^{* * *} \\
(0.0733)\end{array}$ \\
\hline Growth rate of income & $\begin{array}{l}0.352^{* *} \\
(0.175)\end{array}$ & $\begin{array}{l}0.0316 \\
(0.269)\end{array}$ & $\begin{array}{c}0.122 \\
(0.244)\end{array}$ & $\begin{array}{c}0.399 \\
(0.272)\end{array}$ \\
\hline Volatility of income & $\begin{array}{c}-0.0366 \\
(0.128)\end{array}$ & $\begin{array}{c}0.166 \\
(0.152)\end{array}$ & $\begin{array}{l}-0.115 \\
(0.160)\end{array}$ & $\begin{array}{l}-0.111 \\
(0.182)\end{array}$ \\
\hline Sex ratio (number of males per 100 females) & $\begin{array}{c}0.104 \\
(0.133)\end{array}$ & $\begin{array}{c}0.0225 \\
(0.0721)\end{array}$ & & \\
\hline Household Size & & & $\begin{array}{c}-4.594^{* *} \\
(2.060)\end{array}$ & $\begin{array}{c}-3.635^{* * *} \\
(1.401)\end{array}$ \\
\hline SAMPLE YEARS & $2003-09$ & 2003-09 & $2003-09$ & 2003-09 \\
\hline Autonomous regions included & YES & NO & YES & NO \\
\hline Number of provinces / regions / municipalities & 31 & 26 & 31 & 26 \\
\hline Observations & 217 & 182 & 155 & 130 \\
\hline $\begin{array}{l}\text { Arellano Bond test of no second order } \\
\text { autocorrelation in first-differenced } \\
\text { errors ( } p \text {-value) }\end{array}$ & 0.14 & 0.80 & 0.78 & 0.39 \\
\hline
\end{tabular}

Notes: Dependent variable: Urban saving rate. Panel GMM estimation.

Robust standard errors in parentheses. ${ }^{* * *} p<0.01,{ }^{* *} p<0.05,{ }^{*} p<0.1$

Columns 3 and 4 introduce average household size as an additional control. The main coefficient of interest on the real interest variable continues to be negative and significant with the introduction of this new control. The average household size itself is negatively associated with the urban saving rate: as the household size declines across provinces and over time, the urban saving rate rises. The negative coefficient is consistent with the two possible explanations outlined above.

\section{Interactive Effects}

The results from Section $C$ suggest that the real interest rate has had a negative impact on urban saving rates in recent years. The association is robust to the inclusion of other controls that proxy for various savings motives put forward in the micro survey-based literature on 
China. Some of these additional controls themselves are found to influence household saving in a manner consistent with expectations and in line with what previous research has found with alternative datasets.

This section assesses how the decline in interest rates in recent years has interacted with changes in the other determinants to affect household saving. The specification used above is modified by including an additional interaction term

$$
s_{j, t}=\mu_{j}+\beta_{1} Z_{j, t}+\beta_{2} r_{j, t}+\beta_{3} r_{j, t} * Z_{j, t}+\varepsilon_{j, t}
$$

where $\beta_{1}$ captures the influence of the saving motive $Z$ when the real interest is zero, $\beta_{2}$ represents the effect of the real interest rate when $Z$ is zero, and $\beta_{3}$ indicates the additional interactive impact when both $Z$ and the real interest rate depart from zero.

As Table 8 shows, the interaction term is significant in only two cases: columns 4 (household size) and 8 (real property price growth). With regard to the interaction term (real interest rate* household size) in Column 4, one interpretation is that as the household size increases,

Table 8. Interactive Effects, Interest Rates and Other Saving Motives (all provinces)

\begin{tabular}{|c|c|c|c|c|c|c|c|c|}
\hline & (1) & $(2)$ & (3) & (4) & (5) & (6) & (7) & $(8)$ \\
\hline Real interest rate * elderly dependency ratio & $\begin{array}{c}0.0452 \\
(0.0502)\end{array}$ & & & & & & & \\
\hline Real interest rate * dhild dependency ratio & & $\begin{array}{l}0.00439 \\
(0.0208)\end{array}$ & & & & & & \\
\hline Real interest rate ${ }^{*}$ sex ratio & & & $\begin{array}{c}0.0285 \\
(0.0298)\end{array}$ & & & & & \\
\hline Real interest rate * household size & & & & $\begin{array}{l}0.459^{\star *} \\
(0.198)\end{array}$ & & & & \\
\hline Real interest rate * SOE share & & & & & $\begin{array}{c}-0.00657 \\
(0.0136)\end{array}$ & & & \\
\hline Real interest rate * urban property income share & & & & & & $\begin{array}{c}0.263 \\
(0.197)\end{array}$ & & \\
\hline Real interest rate * property prices & & & & & & & $\begin{array}{l}-0.132 \\
(0.158)\end{array}$ & \\
\hline Real interest rate * real property price growth & & & & & & & & $\begin{array}{l}0.0201^{\star \star \star} \\
(0.00643)\end{array}$ \\
\hline SAMPLE YEARS & 2003-09 & $2003-09$ & $2003-09$ & 2003-09 & $2003-09$ & 2003-09 & $2003-09$ & $2003-09$ \\
\hline Autonomous regions included & YES & YES & YES & YES & YES & YES & YES & YES \\
\hline Number of provinces / regions / municipalities & 31 & 31 & 31 & 31 & 31 & 31 & 31 & 31 \\
\hline Observations & 186 & 186 & 217 & 155 & 186 & 186 & 217 & 217 \\
\hline $\begin{array}{l}\text { Arellano Bond test of no second order } \\
\text { autocorrelation in first-differenced } \\
\text { errors ( } p \text {-value) }\end{array}$ & 0.50 & 0.58 & 0.10 & 0.29 & 0.46 & 0.59 & 0.61 & 0.38 \\
\hline
\end{tabular}


this partially offsets the negative relationship between urban saving and the real interest rate. The presence of additional working members in the household, or elderly adults whose savings you can tap into, offers access to an additional pool of saving and so declining real interest rates do not force as strong a saving response as would be the case with smaller households.

One way of interpreting the interaction coefficient in Column 8 is that as real property price growth accelerates, this weakens the negative relationship between real interest rates and urban saving. If we interpret real property price growth as a proxy for an alternative investment return then, as alternative returns increase, urban saving rates are not that strongly affected by the decline in the real interest rates. This is also an indication that financial reform, if it creates a greater menu of higher-paying saving options for households, would allow households to substitute and switch their portfolio toward higher return assets. In turn, this would make it easier for households to meet their target accumulation and could mean they save less and consume more out of disposable income.

The pattern of coefficients in the remaining specifications indicates that the decline in real interest rates in recent years appears not to have affected any of the other saving motives. In particular, as households have seen the real return on their savings steadily decline, they do not appear to have compensated and saved more for any one particular reason from the set suggested by the additional controls considered in Section C. Take the influence of property prices on saving, for example. The level of property prices is positively associated with saving, as seen in Table 6. If households are saving mainly to purchase a home, and if a decline in real interest rates lowers the real return on their saving, households will likely save even more to achieve their desired saving. From equation (2), the response of saving to a small change in property prices $Z$ at negative real interest rates is now given by

$$
\frac{\partial s}{\partial z}=\beta_{1}+\beta_{3} r
$$

Comparing this saving response to a small change in property prices at negative real interest rates with the saving response $\beta_{1}$ at zero real interest rates, we would expect

$$
\left.\frac{\partial s}{\partial Z}\right|_{r<0}>\left.\frac{\partial s}{\partial Z}\right|_{r=0}
$$

In other words, we expect $\beta_{3}$ to be negative and significant. The non-linearity implies that with lower real returns on saving, households are forced to offset this decline in returns by sacrificing a larger fraction of their disposable income. As seen in Table 8, this does not appear to be the case.

Table 9 reports results from the subset of 26 provinces and federal municipalities, excluding autonomous regions. In this case, only the final interaction term in Column 8 is significant and has the same sign as the analogous coefficient in Table 8. 
In general, the absence of significant interaction terms (barring the two cases discussed above) suggests that rather than one over-riding saving motive dominating the others, households target savings accumulation to meet a multiplicity of needs. An increase in the return on saving may enable households to meet their broad target more easily. ${ }^{7}$

Table 9. Interactive Effects, Interest Rates and Other Saving Motives (excluding autonomous regions)

\begin{tabular}{|c|c|c|c|c|c|c|c|c|}
\hline & $(1)$ & $(2)$ & (3) & (4) & (5) & (6) & (7) & (8) \\
\hline Real interest rate * elderly dependency ratio & $\begin{array}{l}-0.0288 \\
(0.0481)\end{array}$ & & & & & & & \\
\hline Real interest rate ${ }^{*}$ child dependency ratio & & $\begin{array}{l}0.00983 \\
(0.0207)\end{array}$ & & & & & & \\
\hline Real interest rate * sex ratio & & & $\begin{array}{l}-0.0152 \\
(0.0224)\end{array}$ & & & & & \\
\hline Real interest rate * household size & & & & $\begin{array}{c}0.231 \\
(0.206)\end{array}$ & & & & \\
\hline Real interest rate * SOE share & & & & & $\begin{array}{c}0.00354 \\
(0.00918)\end{array}$ & & & \\
\hline Real interest rate * urban property income share & & & & & & $\begin{array}{l}-0.0604 \\
(0.0804)\end{array}$ & & \\
\hline Real interest rate * property prices & & & & & & & $\begin{array}{l}-0.141 \\
(0.145)\end{array}$ & \\
\hline Real interest rate * real property price growth & & & & & & & & $\begin{array}{l}0.0208^{* * *} \\
(0.00582)\end{array}$ \\
\hline SAMPLE YEARS & 2003-09 & $2003-09$ & $2003-09$ & 2003-09 & $2003-09$ & $2003-09$ & 2003-09 & $2003-09$ \\
\hline Autonomous regions included & NO & NO & NO & NO & NO & NO & NO & NO \\
\hline Number of provinces / regions / municipalities & 26 & 26 & 26 & 26 & 26 & 26 & 26 & 26 \\
\hline Observations & 156 & 156 & 182 & 130 & 156 & 156 & 182 & 182 \\
\hline $\begin{array}{l}\text { Arellano Bond test of no second order } \\
\text { autocorrelation in first-differenced } \\
\text { errors ( } p \text {-value) }\end{array}$ & 0.99 & 0.91 & 0.93 & 0.41 & 0.89 & 0.99 & 0.11 & 0.59 \\
\hline
\end{tabular}

As this section has demonstrated, the baseline estimates are robust to the inclusion of several additional controls, each of which could affect household saving and also the real interest rate as argued above. Nevertheless, these results should be interpreted with some caveats. First, there could be other factors that also influence the province-level saving rate such as changes in the household income and wealth distribution over the 1990s and 2000s. A more disaggregated, household level data analysis would be required to capture the variation in saving rates induced by shifts in the income and wealth distribution. Second, differences in local government spending across social insurance versus physical infrastructure might introduce variation in provincial social safety nets. In recent years, for example, plenty of measures have been taken to enhance social safety nets. Access to primary health care has been improved through the construction of new health facilities. A new government health

${ }^{7}$ Using a cross-country approach, Guo and N'Diaye (2010) find that given China's level of economic and financial development, an increase in real interest rates would raise consumption. 
insurance program has been launched. On pensions, full portability of benefits has been introduced to enable greater labor mobility. The existing government pension scheme is being expanded to cover urban unemployed workers across the country by end-2012, while the newly introduced rural pension scheme now covers sixty percent of all counties. ${ }^{8}$ The SOE share variable used in the analysis here might not be adequately capturing these differences across provinces that might influence saving behavior. A more detailed breakdown of government expenditures would need to be included in the analysis to reflect the influence of social safety nets on household saving behavior.

The next section discusses possible policy options for lifting the return on saving within the broader agenda of financial reform in China.

\section{INTEREST RATE LIBERALIZATION AND FINANCIAL REFORM}

In recent years, China has made significant progress with strengthening its financial system. Bank balance sheets have been made more robust by shifting nonperforming loans to asset management companies and banks have subsequently been recapitalized. The major banks have been listed on international stock exchanges and the system has become more commercially oriented. Risk management standards have been enhanced and supervisory and regulatory capacity has been significantly widened to cover banking, insurance, and capital markets. Financial market development has proceeded at a steady pace on multiple fronts with the establishment of exchange-traded and interbank bond markets (IMF 2011).

Nevertheless, as Table 1 and Figure 3 above indicate, real interest rates have been declining steadily, as nominal rates have remained below the rate of inflation for close to a decade now (with the exception of 2009, when China experienced deflation). Banks have so far not had to compete aggressively for household deposits since the ceiling on deposit rates limits how far they can go to lure depositors away from competitors and, further, the combination of limited alternative saving options through non-bank channels and capital controls reduce contestability from outside the banking system. But, as attested to by the popularity of wealth management products in recent times, households would move deposits out of the banks to earn higher returns if given more choice regarding saving options. Greater flexibility and choice for household portfolio allocation would exert more competitive pressure on banks, lifting interest rates and the return on household saving in the process. ${ }^{9}$

As outlined in previous IMF work in this area, interest rate liberalization would need to take place within the context of a financial reform agenda which is appropriately-sequenced while also maintaining sufficient flexibility to adapt to evolving circumstances (IMF 2011). Before interest rates can be deregulated to enable them to guide the allocation of saving and credit in the system, the significant existing liquidity overhang in the financial system would need to be drained. Greater exchange rate flexibility, which would minimize the injection of liquidity

\footnotetext{
${ }^{8}$ For details, see IMF (2011).

${ }^{9}$ Feyzioğlu et al. (2009) use model-based simulations to show that interest rate liberalization in China would lift interest rates and the return on saving.
} 
via the balance of payments, and more use of central bank open market operations to influence interbank rates are essential pre-requisites in this regard.

In order to minimize the risks of a disorderly liberalization, loosening of lending standards, and a surge in credit, regulatory and supervisory capabilities would need to be strengthened to close gaps in coverage. With the surplus liquidity drained from the system and an enhanced regulatory framework in place, the authorities can begin liberalizing interest rates by lifting the deposit rate ceiling.

As interest rate liberalization proceeds and a strong regulatory framework is developed, a wider range of saving options could be made more easily accessible to households by encouraging greater participation of mutual funds, money market funds, and insurance-linked investment products in the capital market. This broader financial market development will in time cover a range of securities from equity to corporate fixed income instruments to government bonds across the maturity spectrum.

Finally, the range of instruments and investment options can be expanded to include crossborder claims by removing capital controls and allowing for unrestricted two-way flows of capital. ${ }^{10}$ This could start with FDI and long-term flows before lifting restrictions on shortterm portfolio flows.

Eventually, with this greater flexibility and choice over saving vehicles, households will be able to achieve a more efficient allocation of saving and extract higher returns from their portfolio. As demonstrated in Section IV, an increase in financial rates of return could potentially contribute to a decline in the share of household disposable income that is saved. Combined with the impact of higher interest rates on corporate saving and investment behavior (Geng and N'Diaye, 2011a and 2011b), the cumulative effect of financial reform on the saving-investment imbalance would be large. An appropriately sequenced set of financial reforms therefore could have a substantial impact with regard to rebalancing China's economy.

\section{SUMMARY}

This paper argued that the increase in urban saving rates in China is linked in part to the decline in real interest rates, particularly after 2003. Although the result can be interpreted as a case of the income effect outweighing the substitution effect, this would be a narrow reading of the context in which Chinese households have been making their saving decisions in recent years. In an environment where the underlying fundamentals are changing as rapidly as has been the case in China in the last fifteen years, a more relevant framework for analyzing saving responses is a target saving model. Chinese households appear to save to meet multiple needs including self-insurance, retirement consumption, purchase of durable assets, and act as though they have a target saving accumulation in mind. As real interest rates change, this affects the rate of return on household saving and the degree of difficulty in

\footnotetext{
${ }^{10}$ Lardy and Douglass (2011) argue that interest rate liberalization must precede capital account liberalization to lower the risk of households transferring their deposits out of the banks and thereby undermining the stability of the domestic banking system.
} 
meeting that target saving. For the past decade, the decline in real interest rates seems to have lowered actual savings accumulation below the target. Households appear to have responded by boosting their rate of saving out of current disposable income to lift actual financial wealth closer to the target.

The relationship between real interest rates and the urban saving rate was found to be robust to the inclusion of other variables that proxy for commonly invoked savings impulses such as life cycle considerations or the precautionary motive. The association was also found to be robust to changes in the sample of provinces, moving from the full set of China's 31 provincial-level administrative units to a smaller subset that excludes the five autonomous regions.

The results of this study suggest that financial reform, a sustained increase in the interest rates on bank deposits, and wider access to alternative investment opportunities would make it easier for households to meet their target saving accumulation. To the extent this lowers saving out of current disposable income and lifts private consumption, financial reform could potentially contribute significantly toward rebalancing China’s economy. 


\section{REFERENCES}

Aziz, J. and L. Cui. 2007. "Explaining China’s Low Consumption: The Neglected Role of Household Income.” IMF Working Paper series, 07/181 (Washington: International Monetary Fund).

Banerjee, A., Xin Meng, and N. Qian. 2010. “The Life Cycle Model and Household Savings: Evidence from Urban China.” mimeo, Yale University (New Haven: Yale University).

Batini, N., P. N’Diaye and A. Rebucci. 2005. “The Domestic and Global Impact of Japan’s Policies for Growth.” IMF Working Paper Series, 05/209 (Washington: International Monetary Fund).

Blanchard, O. and F. Giavazzi. 2006. "Rebalancing Growth in China: A Three-Handed Approach," CEPR Discussion Paper 5403.

Cai, Fang, J. Giles, and Xin Meng. 2006. "How Well Do Children Insure Parents Against Low Retirement Income? An Analysis Using Survey Data From Urban China.” Journal of Public Economics, 90, 12, pp. 2229-2255.

Camerer, C., L Babcock, G. Loewenstein, and R. Thaler. 1997. "Labor Supply of New York City Cabdrivers: One Day at a Time” Quarterly Journal of Economics, 112, 2, pp. 407-441

Carroll, C. 1997. "Buffer-Stock Saving and the Life Cycle/Permanent Income Hypothesis.” Quarterly Journal of Economics, 112, 1, pp. 1-55.

Carroll, C. 2001. "A Theory of the Consumption Function, With and Without Liquidity Constraints.” Journal of Economic Perspectives, 15, 3, pp. 23-45.

Chamon, M. and E. Prasad. 2010. "Why Are Saving Rates of Urban Households in China Rising?” American Economic Journal: Macroeconomics, 2, 1, pp. 93-130.

Chamon, M., Kai Liu, and E. Prasad. 2010. "Income Uncertainty and Household Savings in China.” IMF Working Paper, 10/289 (Washington: International Monetary Fund).

Feyzioğlu, T., N. Porter, and E. Takáts. 2009. “Interest Rate Liberalization in China.” IMF Working Paper, 09/171 (Washington: International Monetary Fund).

Geng, N. and P. N’Diaye. 2011a. "Determinants of Corporate Investment in China: Evidence from Cross Country Firm-Level Data.” IMF Working Paper (forthcoming) (Washington: International Monetary Fund).

Geng, N. and P. N’Diaye. 2011b. "Financial Development, Corporate Investment and Savings in China.” IMF Working Paper (forthcoming) (Washington: International Monetary Fund). 
Giles, J. and Ren Mu. 2007. "Elderly Parent Health and the Migration Decision of Adult Children: Evidence from Rural China.” Demography, 44, 2, pp. 265-288.

Giles, J. and K. Yoo. 2007. “Precautionary Behavior, Migrant Networks, and Household Consumption Decisions: An Empirical Analysis Using Household Panel Data from Rural China” Review of Economics and Statistics 89, 3, pp. 534-551.

Guo, K.and P. N’Diaye. 2010. “Determinants of China’s Private Consumption: An International Perspective”. IMF Working Paper, 10/93. Reprinted in Arora V. and R. Cardarelli, eds. Rebalancing Growth in Asia. Economic Dimensions for China. IMF: Washington DC. 2011.

Gu Baochang, Wang Feng, Guo Zhigang, and Zhang Erli. 2007. "China's Local and National Fertility Policies at the End of the Twentieth Century.” Population and Development Review 33, 1, pp. 129-147

Horioka, C. and Junmin Wan. 2007. "The Determinants of Household Saving in China: A Dynamic Panel Analysis of Provincial Data.” Journal of Money, Credit and Banking 39, 8, pp. 2077-2096.

IMF. 2009. Global Crisis: Asian Context. Asia and Pacific Regional Economic Outlook, Spring. http://www.imf.org/external/pubs/ft/reo/2009/APD/eng/areo0509.pdf

IMF. 2011. People’s Republic of China: Staff Report for the 2011 Article IV Consultation. www.imf.org/external/pubs/ft/scr/2011/cr11192.pdf.

Kraay, A. 2000. “Household Saving in China.” World Bank Economic Review 14, 3, pp. 545570.

Kuijs, L. 2006. “How Will China’s Saving - Investment Balance Evolve?” World Bank Policy Research Working Paper 3958 (Washington: World Bank).

Lardy, N. 2008. “Financial Repression in China.” PIIE Policy Brief, 08-8 (Washington: Peterson Institute for International Economics).

Lardy, N. and P. Douglass. 2011. "Capital Account Liberalization and the Role of the Renminbi.” PIIE Working Paper, 11-6 (Washington: Peterson Institute for International Economics).

Laxton, D., P. N'Diaye, and P. Pesenti. 2006. “Deflationary Shocks and Monetary Rules: an Open-Economy Scenario Analysis.” NBER Working Paper 12703 (Cambridge: National Bureau of Economic Research).

Modigliani, F. and Shi Larry Cao. 2004. "The Chinese Saving Puzzle and the Life-Cycle Hypothesis.” Journal of Economic Literature, 42, 1, pp. 145-170. 
Naughton, B. 2007. The Chinese Economy: Transitions and Growth. MIT Press.

Pesenti, P. 2008. “The Global Economy Model (GEM): Theoretical Framework”. Federal Reserve Bank of New York, NBER and CEPR, mimeo.

Wei, Shang-Jin and Xiabo Zhang. (forthcoming) “The Competitive Saving Motive: Evidence from Rising Sex Ratios and Savings Rates in China.” Journal of Political Economy. 